\title{
Relationship between lipopolysaccharide composition and virulence of Haemophilus ducreyi
}

\author{
J. A. ODUMERU, G. M. WISEMAN* and A. R. RONALD
}

\section{Department of Medical Microbiology, University of Manitoba, Winnipeg, Manitoba R3E OW3, Canada}

\begin{abstract}
Summary. The relationship between lipopolysaccharide (LPS) composition and virulence of Haemophilus ducreyi strains was investigated. Glycoses identified in LPS by gas-liquid chromatography were glucose, galactose, and their amino derivatives glucosamine and galactosamine. Fucose was found in trace amounts but mannose and rhamnose, characteristic of the O-side chain of LPS in many species, were not detected. Qualitatively, the LPS composition of the eight strains examined was similar and differences were mainly quantitative. The total glycose:KDO ratio of the LPS of virulent strains exceeded that of avirulent strains. All strains had similar fatty-acid composition but lacked lauric acid. SDS-polyacrylamide gel electrophoresis of the LPS of virulent and avirulent strains also revealed differences in their electrophoretic mobilities. The LPS profiles of avirulent strains were similar, but differed from those of virulent strains. These profiles lacked high mol. wt bands representing $\mathrm{O}$-side chain repeating units. Thus, differences in the electrophoretic mobilities of the LPS of virulent and avirulent strains may reflect differences in the amount of carbohydrates associated with the core polysaccharide.
\end{abstract}

\section{Introduction}

Lipopolysaccharide (LPS) is a major component of the outer membrane of gram-negative bacteria. Structurally, it consists of three parts: lipid A, core polysaccharide and $\mathrm{O}$-antigenic side chains. The $\mathrm{O}-$ antigenic side chains are found in smooth LPS, whereas rough LPS may contain lipid A and varying amounts of the core polysaccharide or lipid $A$ and 2-keto-3-deoxy-octulosonic acid (KDO) only, as in the case of deep rough mutants (Luderitz et al., 1971). The presence of O-antigenic side chains in the LPS of smooth strains of Salmonella spp. (Nelson and Roantree, 1967; Rowley, 1968; Olling, 1977), Escherichia coli (Mushel and Larsen, 1970; Taylor, 1975), and Shigella spp. (Reed and Albright, 1974) and the composition of the core polysaccharide of E. coli (Medearis et al., 1968) and the LPS of Neisseria gonorrhoeae (Guymon et al., 1982) have been associated with serum resistance and virulence.

In a previous study (Odumeru et al., 1984), virulence of Haemophilus ducreyi was associated with resistance both to the bactericidal action of

Received 31 Dec. 1985; revised version accepted 6 May 1986.

* Correspondence should be sent to Professor G. M. Wiseman, Department of Medical Microbiology, Room 514, Basic Medical Sciences Building, 730 William Avenue, Winnipeg, Manitoba R3E OW3, Canada. human serum and to phagocytosis and killing by human polymorphonuclear leukocytes. The bactericidal effect of human serum was inhibited by the LPS of serum-sensitive strains but not by the LPS of serum-resistant strains (Odumeru et al., 1985). The purpose of the present study was to determine whether there is a relationship between the chemical composition of the LPS of $H$. ducreyi strains and virulence and whether the gross chemical composition of $H$. ducreyi LPS resembled that of LPS from other gram-negative species.

\section{Materials and methods}

\section{Bacterial strains and growth conditions}

$H$. ducreyi strains used in this study were: reference strains A75, A77, and A76 (from the Pasteur Institute, Paris); strain 36-F-2 (from M. Kilian); strains 409, C148, 557, BG411 (from Kenya); strains 35000 and 78226 (from Winnipeg); and strain $\mathrm{CH} 39$ (from Thailand). Serumresistant strain $\mathrm{A} 77^{*}$ was obtained by passage of strain A77 in the presence of increasing concentrations of pooled normal human serum until a $70 \%$ survival rate in $50 \%$ serum was reached.

The strains were kept as frozen-milk stock cultures at $-70^{\circ} \mathrm{C}$. Before use, they were cultured on haemoglobin agar composed of gonococcal medium base and $1 \%$ Isovitalex and incubated at $35^{\circ} \mathrm{C}$ with $\mathrm{CO}_{2} 5 \%$ and high humidity for $24 \mathrm{~h}$. All media were obtained from Gibco 
Laboratories, Madison, WI, USA. No visual evidence of capsulation was present.

\section{Virulence tests}

Virulence of $\boldsymbol{H}$. ducreyi strains was tested by the intradermal injection (Hammond et al., 1978) of $0.20 \mathrm{ml}$ of Sheep Brain Heart Infusion Broth (Gibco) containing $10^{9} \mathrm{cfu} / \mathrm{ml}$ of $H$. ducreyi into $2-3 \mathrm{~kg}, 1$-year-old female rabbits. Induration and necrosis were determined daily from day 1 until day 11 after inoculation. The criteria for virulence were that induration exceeded $0.5 \mathrm{~cm}$ by day 4 , and the lesion progressed to an eschar by day $11 . H$. ducreyi strains 409, 35000, A77*, C148, BG411, 557 and $\mathrm{CH} 39$ were virulent but strains $\mathrm{A} 77, \mathrm{~A} 75, \mathrm{~A} 76$, and $36-\mathrm{F}$ 2 were avirulent by these criteria.

\section{LPS isolation}

The LPS of $H$. ducreyi strains was isolated by the rapid isolation micromethod described by Inzana (1983), and also from $18 \mathrm{~g}$ (wet weight) of stationary phase cells by the hot phenol-water procedure of Westphal and Jann (1965). All LPS preparations were lyophilised and stored at $4^{\circ} \mathrm{C}$. The LPS of non-pilated $N$. gonorrhoeae $P-6472$ was supplied by Dr G. M. Wiseman. LPS of E. coli $0111 B_{4}$ was obtained from Difco Laboratories, Detroit, MI, USA.

\section{Preparation of lipid A from LPS}

Lipid A was prepared as described by Stead et al. (1975). About $30 \mathrm{mg}$ of LPS was hydrolysed with $5 \mathrm{ml}$ of $0 \cdot 18 \mathrm{M}$ acetic acid at $100^{\circ} \mathrm{C}$ for $2 \mathrm{~h}$ in a sealed ampoule. The precipitated lipid A was removed by centrifugation, washed with $0 \cdot 18 \mathrm{M}$ acetic acid, lyophilised and weighed.

\section{Fatty acid analysis}

Fatty acid methyl esters were prepared as described by Jennings et al. (1973). Lyophilised lipid A was dissolved in chloroform, reprecipitated in acetone (1 part lipid: 3 parts acetone), and refluxed in methanolic $\mathrm{HCl}$ ( 5 parts methanol: 1 part $\mathrm{HCl}$ ) for $8 \mathrm{~h}$. The methyl esters were extracted with ethyl ether-petroleum ether ( $1: 1)$, concentrated, and analysed by gas-liquid chromatography (GLC) on a stainless-steel column $(0.65 \times 180 \mathrm{~cm})$ prepacked with $10 \%$ diethylene glycol adipate (DEGA) and $2 \%$ phosphoric acid on 100-120-mesh Gas-Chrom Q. Oven temperature was programmed as follows: $120^{\circ} \mathrm{C}$ for 4 min, temperature rising at $6^{\circ} \mathrm{C} / \mathrm{min}$, and $250^{\circ} \mathrm{C}$ for $5 \mathrm{~min}$. The detector was held at $250^{\circ} \mathrm{C}$. Known standards were used for comparison in all GLC methods.

\section{Analytical methods}

Total carbohydrate was measured as described by Dubois et al. (1956), and total hexose was assayed by the anthrone sulphuric acid method of Scott and Melvin (1953). Glucose was used as standard in both assays. The protein content was determined by the method of Bradford (1976) and the colorimetric method of Ceriotti (1952) was applied to the determination of deoxyribonucleic acid. Heptose was determined by the Dische method as modified by Wright and Rebers (1972) with glucoheptose as a standard. Aminoglycoses were quantitated by the method of Smith and Gilkerson (1979). N-acetylneuraminic acid (NANA) was determined by the periodateresorcinol method of Jourdian et al. (1971) and phosphorus was determined as described by Fiske and Subbarrow (1925). KDO was estimated by the thiobarbituric acid (TBA) method of Karkhanis et al. (1978), and also by the method of Brade et al. (1983).

Glycose analyses were performed as described by Wiseman and Caird (1977) with slight modifications. About $30 \mathrm{mg}$ of LPS was hydrolysed with $1 \mathrm{~N}_{2} \mathrm{SO}_{4}$ for 4 $\mathrm{h}$ at $100^{\circ} \mathrm{C}$ in a sealed ampoule. The hydrolysate was neutralised with solid $\mathrm{BaCO}_{3}$, centrifuged and the supernate was lyophilised. The lyophilised material was treated with $0.1 \mathrm{ml}$ Sil-Prep reagent (Sigma Chemical Co., St Louis, MO, USA) (pyridine $0.5 \mathrm{ml}$; hexamethyldisilazane $0.15 \mathrm{ml}$; trimethylchlorosilane $0.1 \mathrm{ml}$ ) for each $\mathrm{mg}$ of material and shaken vigorously. The reaction was allowed to proceed for $60 \mathrm{~min}$ at room temperature and the trimethysilylated (TMS) monosaccharides were analysed in a Pye 104 gas-liquid chromatograph equipped with dual hydrogen flame ionisation detectors. The separation of the various monosaccharides was achieved in a stainless steel column $(0.65 \times 180 \mathrm{~cm})$ prepacked with $10 \%$ SE30 on 100-120-mesh Gas-Chrom Q in a temperature programme over the range $150-250^{\circ} \mathrm{C}$ and rising at $2^{\circ} \mathrm{C} / \mathrm{min}$. The detector temperature was $250^{\circ} \mathrm{C}$.

Aminoglycoses were determined by GLC, as described by Laine et al. (1972).

\section{SDS-polyacrylamide gel electrophoresis (SDS- $P A G E$ )}

The LPS preparations from $H$. ducreyi strains were analysed by SDS-PAGE with the discontinuous gel system described by Laemmli (1970). The gel was $15 \%$ polyacrylamide and contained $4 \mathrm{M}$ urea. In the electrophoretic analysis of LPS preparations, $2 \mu \mathrm{g}$ of purified LPS was loaded on to the gel and electrophoresed at 20 $\mathrm{mA}$ (constant current) per slab. After electrophoresis, the LPS bands were visualised by the silver staining method of Tsai and Frasch (1982). The electrophoretic mobility and profiles of LPS isolated by the methods of Inzana (1983) and Westphal and Jann (1965), were similar.

\section{Infra-red spectrophotometry}

Infra-red (IR) spectra of the LPS preparations were obtained with the assistance of the Chemistry Department, University of Manitoba. Lyophilised, dried LPS was ground with Nujol (mineral-oil), placed in cells and scanned. 


\section{Results}

\section{Chemical analysis of LPS}

The chemical composition of the LPS preparations from virulent strains of $H$. ducreyi was compared with that of avirulent strains. The LPS of E. coli $0111 \mathrm{~B}_{4}$ and $N$. gonorrhoeae $\mathrm{P}^{-} 6274$ were included for comparison. Qualitatively, the major components of all LPS preparations were similar (table I). These LPS preparations were characterised by a nucleic acid content of $<1 \%$ and a protein content of $\leqslant 2 \%$. The total carbohydrate, hexose, and NANA contents of virulent strains were relatively higher than those of the avirulent strains. In contrast, the lipid A content was higher in avirulent strains. Other LPS components varied between strains and there was no correlation between the amount and virulence.

The concentration of the components of the LPS

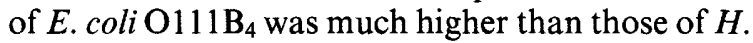
ducreyi strains and $N$. gonorrhoeae $\mathrm{P}^{-} 6472$, except lipid A, NANA and phosphate concentrations which were lower than those of $H$. ducreyi.

The KDO content of the LPS of $H$. ducreyi strains and $N$. gonorrhoeae $\mathrm{P}^{-} 6472$ was $<1 \%$ when LPS was hydrolysed with $0.2 \mathrm{~N} \mathrm{H}_{2} \mathrm{SO}_{4}$ (table II). Hydrolysis of LPS with $4 \mathrm{~N} \mathrm{HCl}$ released KDO from the LPS in amounts similar to that released from $E$. coli $0111 \mathrm{~B}_{4}$. The amount of KDO released from $N$. gonorrhoeae LPS by $4 \mathrm{~N} \mathrm{HCl}$ was substantially higher than that from $E$. coli and $H$. ducreyi.

\section{Identification of glycoses}

Hexoses and hexosamines identified in the LPS of $H$. ducreyi strains by GLC were glucose, galactose, glucosamine and galactosamine (table III). Ribose in the concentration range $0 \cdot 01-0.2 \mathrm{nmol} / \mu \mathrm{g}$ of LPS was present. Fucose was present in trace amounts but mannose and rhamnose were not detected. Rhamnose was also absent from LPS of $N$. gonorrhoeae $\mathrm{P}-6472$ but these sugars were identified in $E$. coli $0111 \mathrm{~B}_{4}$. The total hexose: hexosamine concentration of the LPS of virulent strains 35000, 409, $\mathrm{C} 148$, and $\mathrm{A} 77^{*}$ exceeded that of avirulent strains A76, 36-F-2, A77, and A75.

Total glycose:KDO ratios for virulent strains were also higher than those of avirulent strains (table II). This ratio for nonpilated $N$. gonorrhoeae $\mathrm{P}^{-} 6472$ was in the same range as those of the avirulent $H$. ducreyi strains.

\section{Identification of fatty acids}

$\mathrm{C} 14, \mathrm{C} 16, \mathrm{C} 18$, and $\mathrm{C} 20$ fatty acids were identified by GLC in the lipid A moiety of $H$. ducreyi

Table I. Chemical composition of lipopolysaccharides isolated from H. ducreyi, E. coli and N. gonorrhoeae

\begin{tabular}{|c|c|c|c|c|c|c|c|c|c|}
\hline \multirow[b]{2}{*}{ Strain } & \multicolumn{9}{|c|}{ Percentage (dry wt) of lipopolysaccharide* } \\
\hline & $\begin{array}{l}\text { Total } \\
\text { carbo- } \\
\text { hydrate }\end{array}$ & $\begin{array}{l}\text { Total } \\
\text { hexose }\end{array}$ & $\begin{array}{l}\text { Hexo- } \\
\text { samine }\end{array}$ & $\begin{array}{l}\text { Hep- } \\
\text { tose }\end{array}$ & $\begin{array}{l}\text { Pro- } \\
\text { tein }\end{array}$ & $\begin{array}{l}\text { Nucleic } \\
\text { acid }\end{array}$ & $\begin{array}{l}\text { Phos- } \\
\text { phate }\end{array}$ & NANA & $\begin{array}{l}\text { Lipid } \\
\text { A }\end{array}$ \\
\hline \multicolumn{10}{|l|}{$\begin{array}{l}\text { H. ducreyi } \\
\text { (virulent) }\end{array}$} \\
\hline 35000 & $25 \cdot 6$ & $20 \cdot 3$ & $7 \cdot 3$ & $7 \cdot 1$ & $2 \cdot 0$ & $0 \cdot 3$ & $4 \cdot 5$ & $3 \cdot 7$ & $41 \cdot 3$ \\
\hline 409 & $26 \cdot 8$ & $20 \cdot 0$ & $5 \cdot 4$ & 6.5 & 1.8 & 0.4 & $4 \cdot 8$ & $3 \cdot 7$ & 32.6 \\
\hline $\mathrm{Cl} 48$ & $24 \cdot 5$ & $16 \cdot 8$ & $5 \cdot 5$ & $5 \cdot 2$ & 1.7 & 0.5 & $4 \cdot 7$ & $2 \cdot 7$ & 35.8 \\
\hline $\mathrm{A} 77^{*}$ & 25.9 & $19 \cdot 7$ & $6 \cdot 3$ & $7 \cdot 8$ & 1.9 & 0.8 & $4 \cdot 6$ & $3 \cdot 1$ & $32 \cdot 5$ \\
\hline \multicolumn{10}{|l|}{ (avirulent) } \\
\hline A77 & $20 \cdot 7$ & 11.8 & 5.8 & $8 \cdot 0$ & 1.8 & $0 \cdot 3$ & $4 \cdot 8$ & $2 \cdot 8$ & $47 \cdot 5$ \\
\hline A75 & $22 \cdot 8$ & $13 \cdot 5$ & $7 \cdot 0$ & $7 \cdot 4$ & 0.9 & $0 \cdot 3$ & $5 \cdot 1$ & $1 \cdot 2$ & 43.6 \\
\hline $36-F-2$ & $19 \cdot 0$ & $13 \cdot 0$ & $4 \cdot 1$ & 8.0 & $1 \cdot 1$ & $0 \cdot 2$ & 4.8 & $1 \cdot 2$ & 42.5 \\
\hline A76 & $20 \cdot 3$ & 12.6 & $5 \cdot 6$ & $7 \cdot 8$ & $1 \cdot 3$ & $0 \cdot 3$ & $5 \cdot 3$ & $2 \cdot 2$ & $48 \cdot 5$ \\
\hline \multicolumn{10}{|l|}{ E. coli } \\
\hline $0111 B_{4}$ & $44 \cdot 5$ & $34 \cdot 7$ & $23 \cdot 3$ & $12 \cdot 5$ & $0 \cdot 8$ & 0.9 & $3 \cdot 5$ & $0 \cdot 6$ & $25 \cdot 1$ \\
\hline $\begin{array}{l}\text { N. gonorrhoeae } \\
\mathrm{P}^{-} 6472\end{array}$ & $30 \cdot 0$ & 21.8 & $5 \cdot 5$ & $4 \cdot 5$ & $2 \cdot 1$ & 0.6 & $4 \cdot 3$ & 0.9 & $15 \cdot 5$ \\
\hline
\end{tabular}

NANA $=\mathrm{N}$-acetylneuraminic acid.

* Mean of three separate determinations. 
Table II. KDO content of LPS preparations from $H$. ducreyi, E. coli and $N$. gonorrhoeae

\begin{tabular}{|c|c|c|c|c|}
\hline \multirow[b]{2}{*}{ Strain } & \multicolumn{2}{|c|}{ Karkhanis Method* } & \multicolumn{2}{|c|}{ Brade Method $\dagger$} \\
\hline & $\begin{array}{c}\text { Per cent } \\
\text { KDO }\end{array}$ & $\begin{array}{c}\text { Ratio } \\
\text { Glycose:KDO }\end{array}$ & $\begin{array}{l}\text { Percent } \\
\text { KDO }\end{array}$ & $\begin{array}{c}\text { Ratio } \\
\text { Glycose:KDO }\end{array}$ \\
\hline \multicolumn{5}{|l|}{$\begin{array}{l}\text { H. ducreyi } \\
\text { (virulent) }\end{array}$} \\
\hline 35000 & $0.7 \ddagger$ & $2 \cdot 8$ & $4 \cdot 0$ & 0.49 \\
\hline 409 & $0.6^{6}$ & $3 \cdot 7$ & $4 \cdot 0$ & 0.57 \\
\hline C148 & 0.4 & $3 \cdot 5$ & 3.8 & 0.37 \\
\hline A77* & 0.7 & $3 \cdot 1$ & $4 \cdot 4$ & 0.50 \\
\hline \multicolumn{5}{|l|}{ (avirulent) } \\
\hline A77 & 0.7 & $1 \cdot 3$ & $4 \cdot 4$ & $0 \cdot 20$ \\
\hline A75 & 0.6 & 1.9 & $4 \cdot 3$ & 0.27 \\
\hline $36-F-2$ & 0.6 & $1 \cdot 6$ & $3 \cdot 8$ & 0.31 \\
\hline A76 & $0 \cdot 6$ & 1.9 & $4 \cdot 2$ & 0.23 \\
\hline $\begin{array}{l}\text { E. coli } \\
0111 \mathrm{~B}_{4}\end{array}$ & $3 \cdot 4$ & 0.9 & $4 \cdot 3$ & 0.71 \\
\hline N. gonorrhoeae & & & & \\
\hline$P-6472$ & 0.9 & 1.8 & $7 \cdot 6$ & 0.21 \\
\hline
\end{tabular}

$\mathrm{KDO}=2$-Keto-3-deoxyoctulosonic acid.

* KDO released by $0.2 \mathrm{~N} \mathrm{H}_{2} \mathrm{SO} 4$ (Karkhanis et al., 1978).

$\uparrow \mathrm{KDO}$ released by $4 \mathrm{~N} \mathrm{HCl}$ (Brade et al., 1983).

$\ddagger$ Each figure represents the mean of three separate determinations.

Table III. Monosaccharide content of the LPS from $H$. ducreyi, $N$. gonorrhoeae and E. coli

\begin{tabular}{|c|c|c|c|c|c|c|c|c|}
\hline \multirow[b]{2}{*}{ Strain } & \multicolumn{8}{|c|}{ Glycose concentration* $(\mathrm{nmol} / \mu \mathrm{g}$ of LPS) } \\
\hline & $\begin{array}{l}\text { Glu- } \\
\text { cose }\end{array}$ & $\begin{array}{c}\text { Galac- } \\
\text { tose }\end{array}$ & $\begin{array}{l}\text { Man- } \\
\text { nose }\end{array}$ & $\begin{array}{l}\text { Rham- } \\
\text { nose }\end{array}$ & Fucose & $\begin{array}{l}\text { Gluco- } \\
\text { samine }\end{array}$ & $\begin{array}{l}\text { Galacto- } \\
\text { samine }\end{array}$ & Total \\
\hline \multicolumn{9}{|l|}{$\begin{array}{l}\text { H. ducreyi } \\
\text { (virulent) }\end{array}$} \\
\hline $\mathrm{C} 148$ & 0.41 & $0 \cdot 30$ & 0 & 0 & 0.04 & $0 \cdot 42$ & $0 \cdot 25$ & $1 \cdot 42$ \\
\hline 409 & $0 \cdot 81$ & 0.53 & 0 & 0 & 0.04 & $0 \cdot 51$ & $0 \cdot 38$ & $2 \cdot 27$ \\
\hline 35000 & 0.71 & 0.48 & 0 & 0 & $0 \cdot 01$ & 0.47 & $0 \cdot 30$ & 1.97 \\
\hline A $77^{*}$ & 0.79 & $0 \cdot 41$ & 0 & 0 & 0.06 & 0.52 & $0 \cdot 41$ & $2 \cdot 19$ \\
\hline \multicolumn{9}{|l|}{ (avirulent) } \\
\hline A 77 & $0 \cdot 27$ & $0 \cdot 19$ & 0 & 0 & 0.01 & 0.32 & 0.12 & 0.91 \\
\hline A75 & 0.48 & $0 \cdot 33$ & 0 & 0 & 0.01 & $0 \cdot 20$ & $0 \cdot 16$ & $1 \cdot 18$ \\
\hline A 76 & 0.34 & 0.21 & 0 & 0 & 0.005 & $0 \cdot 24$ & $0 \cdot 16$ & 0.955 \\
\hline $36-F-2$ & 0.40 & $0 \cdot 26$ & 0 & 0 & 0.01 & $0 \cdot 31$ & $0 \cdot 21$ & $1 \cdot 19$ \\
\hline \multicolumn{9}{|l|}{ N. gonorrhoeae } \\
\hline$P^{-6472}$ & 0.64 & 0.44 & 0.02 & 0 & $0 \cdot 15$ & $0 \cdot 31$ & $0 \cdot 17$ & 1.73 \\
\hline \multicolumn{9}{|l|}{ E. coli } \\
\hline $\mathrm{O} 111 \mathrm{~B}_{4}$ & $1 \cdot 10$ & 0.69 & $0 \cdot 36$ & 0.03 & 0.04 & $0 \cdot 56$ & $0 \cdot 31$ & 3.09 \\
\hline
\end{tabular}

* Determined by GLC as TMS derivatives. 
Table IV. Lipid A fatty acid content of $H$. ducreyi and E. coli $\mathrm{O}_{111 \mathrm{~B}_{4}}$

\begin{tabular}{l|llllll}
\hline & \multicolumn{6}{|c}{$\begin{array}{l}\text { Concentrations (nmol/ } \mu \mathrm{g} \text { of lipid } \\
\text { A) of fatty acids of chain length }\end{array}$} \\
\cline { 2 - 7 } \multicolumn{1}{c}{ Strain } & $\mathrm{C} 12$ & $\mathrm{C} 14$ & $\mathrm{C} 16$ & $\mathrm{C} 18$ & $\mathrm{C} 20$ \\
\hline H. ducreyi & & & & & \\
409 & 0 & $0.61 \dagger$ & $0.06 \dagger$ & 0.10 & 0.05 \\
35000 & 0 & 0.65 & 0.04 & 0.12 & 0.05 \\
A77* & 0 & 0.72 & 0.03 & 0.14 & 0.03 \\
A77 & 0 & 0.68 & 0.04 & 0.10 & 0.07 \\
A75 & 0 & 0.70 & 0.04 & 0.14 & 0.07 \\
$36-\mathrm{F}-2$ & 0 & 0.75 & 0.06 & 0.16 & 0.07 \\
A76 & 0 & 0.61 & 0.04 & 0.16 & 0.08 \\
E. coli & & & & & \\
$111 B_{4}$ & 0.17 & 0.58 & 0.22 & 0.09 & 0.05 \\
\hline
\end{tabular}

† Values represent the fatty acid concentrations ( $\mathrm{nmol} / \mu \mathrm{g}$ lipid $\mathrm{A}$ ), as determined by GLC.

strains (table IV). $\mathrm{C}_{12}$ (lauric) acid, was identified in $E$. coli, but was absent in $H$. ducreyi strains. $\mathrm{OH}$ substituted $\mathrm{C}_{14}$ ( $\beta$-hydroxymyristic) acid was identified tentatively in $E$. coli and $H$. ducreyi, based on the relative retention time of this acid. However, no standard was available at the time of analysis to confirm the identification.

Quantitatively, there was little difference in fatty acid content between virulent and avirulent $H$. ducreyi. It has been suggested (Rietschel et al., 1984) that $\mathrm{C} 18$ and $\mathrm{C} 20$ acids in $E$. coli $0111 \mathrm{~B}_{4}$ commercial LPS preparations are phospholipid contaminants, but this cannot be ascertained with certainty for the $H$. ducreyi strains.

\section{SDS-Page of LPS}

The electrophoretic profiles of the LPS of virulent and avirulent $H$. ducreyi are shown in fig. 1. Patterns of the avirulent strains (lanes A-D) appeared similar to each other but differed from the patterns of the virulent strains (lanes E-K). The LPS profile of serum-resistant isogenic strain $\mathrm{A} 77^{*}$ in lane $\mathrm{E}$ differed from that of serum-sensitive parent strain A77 in lane D. The isogenic strain was virulent in the rabbit model, whereas the parent strain was avirulent.

The LPS profiles of all $H$. ducreyi strains examined lacked the high mol. wt subunits present in the LPS of E. coli (lane I) (fig. 2). Such bands apparently represent the O-side chains of smooth LPS (Jann et al., 1975).

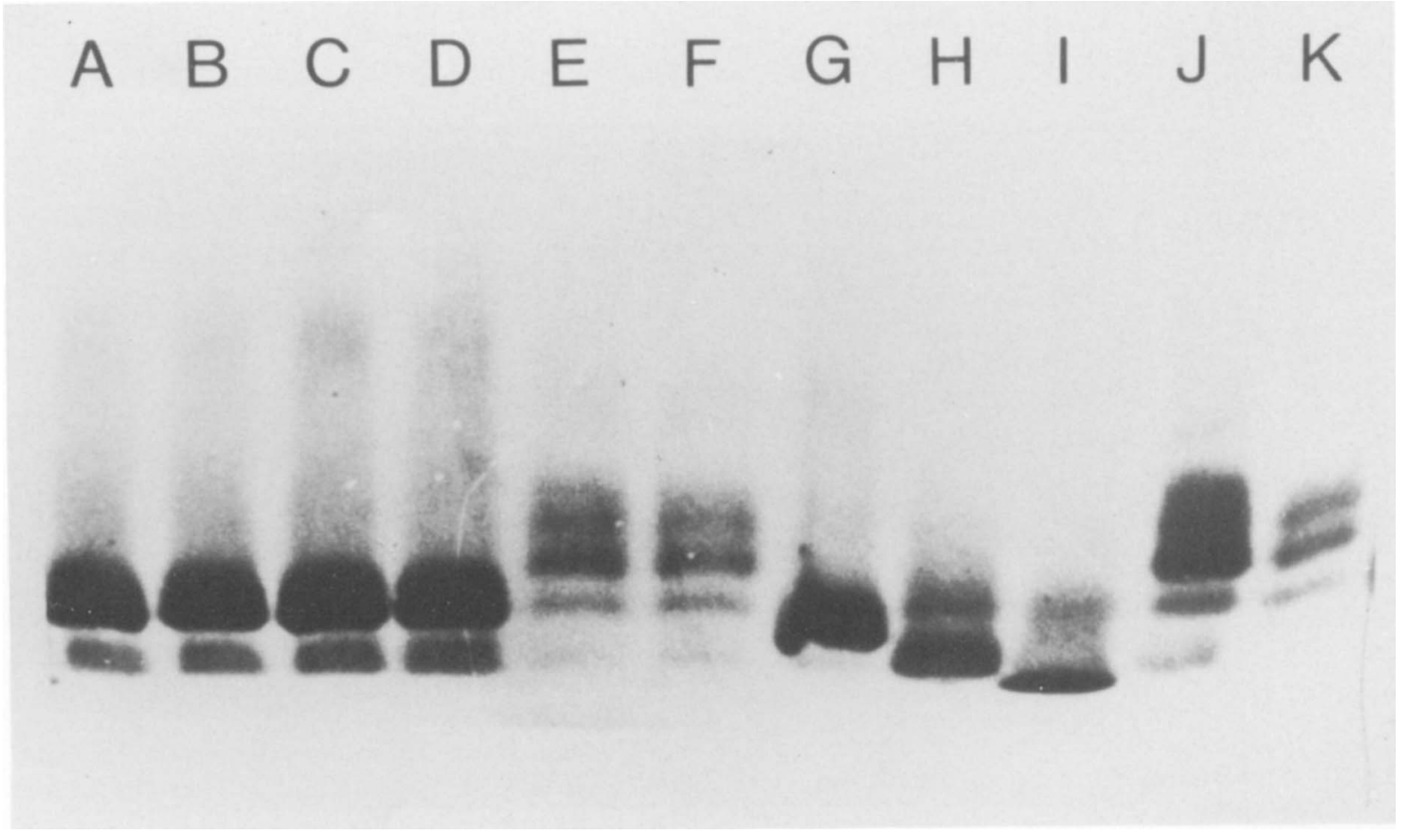

Fig. 1. Electrophoretic profiles of the LPS of $H$. ducreyi. Avirulent strains: lanes A, 36-F-2; B, A76; C, A75; D, A77. Virulent strains: lanes E, A77*; F, 35000; G, 557; H, CH39; I, BG411; J, 409; K, 78226. 


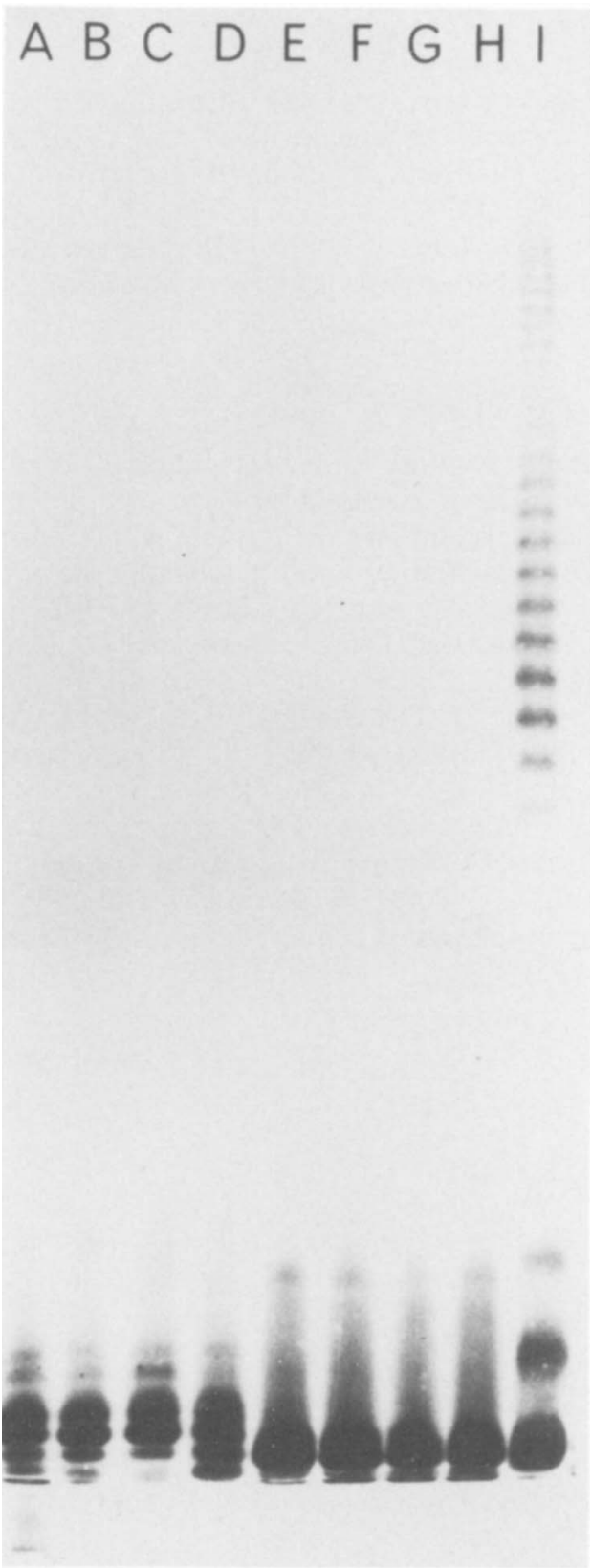

Fig. 2. Electrophoretic profiles of the LPS of $H$. ducreyi strains and $E$. coli $\mathrm{Ol11B}_{4}$. H. ducreyi strains: lanes A, C148; B, 35000; C, A77*; D, 409; E, A77; F, A75; G, A76; H, 36-F-2; lane I, E. coli O111B $\mathrm{B}_{4}$. Each well contained $2 \mu \mathrm{g}$ of LPS.

\section{Infra-red spectra}

The IR spectra of the LPS of $H$. ducreyi A76, 35000,409 , and $\mathrm{A} 77^{*}$ were identical and were similar to those of $E$. coli $0111 \mathrm{~B}_{4}$ and $N$. gonorrhoeae $\mathrm{P}^{-} 6274$ (fig. 3). The spectra contained broad absorption peaks at $3350 / \mathrm{cm}$ attributed to hydroxyl radicals characteristic of carbohydrates. Absorption bands at 1650 and 1510 to 1550 were due to monosubstituted amide groups $\left(-\mathrm{NH} \cdot \mathrm{CO} \cdot \mathrm{CH}_{3}\right)$. The presence of an ester carbonyl band at $1720 / \mathrm{cm}$ and the broad absorption in the range from 1000/ $\mathrm{cm}$ to $12000 / \mathrm{cm}$ characterised the LPS preparation as containing fatty acid esters. IR scans of $H$. ducreyi LPS lacked the sharp absorption bands at $1275 / \mathrm{cm}$ and the fatty acid ester band at $1300 / \mathrm{cm}^{-1}$, which were present in the $E$. coli LPS scan.

\section{Discussion}

The gross chemical composition of the LPS of $H$. ducreyi strains was similar to that of other gramnegative bacteria, as indicated by IR spectra and chemical analysis. Although there were no qualitative differences in the LPS of virulent and avirulent $H$. ducrey $i$ strains, the total glycose:KDO ratio of the LPS of virulent strains exceeded that of avirulent strains. Glycoses such as rhamnose and mannose which are characteristic of the $\mathrm{O}$-specific chains of the LPS of many gram-negative bacteria were not identified in $H$. ducreyi. Thus, differences appear to reside in the core polysaccharide. Virulent strains, in contrast to avirulent strains, have been shown previously (Odumeru et al., 1984) to be resistant to complement-mediated bactericidal action of human and rabbit serum. Strain C148 which has a lower glycose:KDO ratio (table II) than virulent strains 35000,409 , and A77 was less resistant to the bactericidal action of serum than these strains (Odumeru et al., 1984). Strains A77, A74, and A76 which had the lowest glycose: KDO ratios, were susceptible to the bactericidal action of serum (Odumeru et al., 1984). Thus, differences in the serum-sensitivity of strains may be associated with the amount of carbohydrate present in the core region of the LPS.

The KDO content of $H$. ducreyi and $N$. gonorrhoeae $\mathrm{P}^{-} 6472$ was low $(<1 \%)$, compared with that of $E$. coli $0111 \mathrm{~B}_{4}(3 \cdot 5 \%)$, when $0 \cdot 2 \mathrm{~N} \mathrm{H}_{2} \mathrm{SO}_{4}$ was used in hydrolysis. Low KDO content has been reported for $H$. influenzae types a-f (Zoon and Scocca, 1975; Flesher and Insel, 1978). However, Parr and Bryan (1984) detected KDO in three strains of $H$. influen$z a e$ at levels similar to that in a strain of $S$. typhimurium (c. 3\%), by hydrolysing LPS with $4 \mathrm{~N}$ $\mathrm{HCl}$, as described previously by Brade et al. (1983). Hydrolysis of $H$. ducreyi LPS with $4 \mathrm{~N} \mathrm{HCl}$ yielded more TBA-reactive material producing KDO levels similar to that of $E$. coli $0111 \mathrm{~B}_{4}$. This procedure frees C-4 and C-5 substituted KDO from LPS (Brade et al., 1983), indicating that $\mathrm{KDO}$ in $H$. ducreyi is highly substituted. The same is true of $N$. 


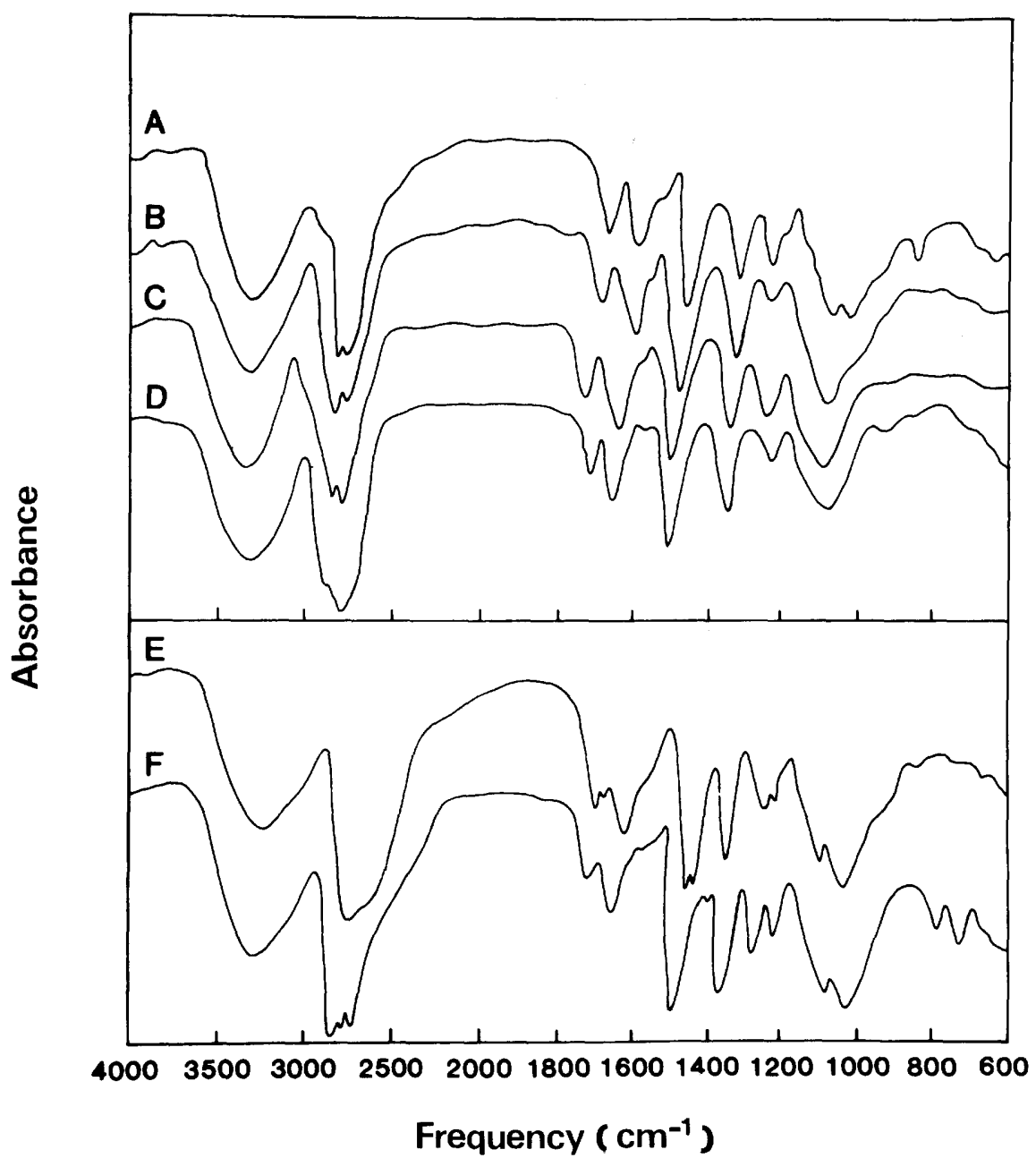

Fig. 3. Infra-red spectra of the lipopolysaccharides of $H$. ducreyi strains: A77* (A), A76 (B), 35000 (C), 409 (D); $N$. gonorrhoeae $\mathrm{P}^{-} 6472(\mathrm{E})$; and E. coli $\mathrm{O} 111 \mathrm{~B}_{4}(\mathrm{~F})$.

gonorrhoeae $\mathrm{P}^{-} 6472$ LPS, in which $\mathrm{KDO}$ at levels higher than $E$. coli and $H$. ducreyi was detected after strong acid hydrolysis.

SDS-PAGE analysis of LPS revealed differences in the electrophoretic profiles of virulent and avirulent strains. The profiles of avirulent strains were similar, but differed from those of virulent strains as exemplified by serum-resistant isogenic strain $\mathrm{A} 77^{*}$ which is virulent, and serum-sensitive parent strain A77 which is avirulent in the rabbit model. $H$. ducreyi strains contained LPS of low mol. wt, suggesting that the O-side chains typical of smooth LPS of E. coli, Salmonella spp., and Shigella spp. (Luderitz et al., 1971; Jann et al., 1975) are not present in these strains. These observations support the chemical data that glycoses characteristic of $\mathrm{O}$ side chain LPS such as mannose and rhamnose were not detected. However, the non-pilated $N$. gonorr- hoeae 6472 contained a trace amount of mannose. Thus, differences in mobility of the LPS of virulent and avirulent strains may reflect differences in the amount of carbohydrates associated with the core polysaccharide. Other gram-negative bacteria such as $N$. meningitidis, $N$. gonorrhoeae, Bordetella pertussis, $H$. influenzae, and also Chlamydia spp. have a "rough type" LPS (Tsai and Frasch, 1982; Inzana, 1983; Caldwell and Hitchcock, 1984; Logan and Trust, 1984; Peppler, 1984), indicating that "smooth" type LPS is not a prerequisite for virulence of these organisms.

We acknowledge the advice of Drs G. H. Bowden and E. T. Pritchard of the Department of Oral Biology, in regard to GLC analysis of LPS.

This research was supported by a Medical Research Council of Canada grant to Dr A. R. Ronald. One of us (J.A.O.) is the recipient of a Manitoba Health Research Council Studentship. 


\section{REFERENCES}

Brade H, Galanos C, Lüderitz O 1983 Differential determination of the 3-deoxy-D-mannooctulosonic acid residues in lipopolysaccharides of Salmonella minnesota rough mutants. European Journal of Biochemistry 131:195-200.

Bradford M M 1976 A rapid and sensitive method for the quantitation of microgram quantities of protein utilizing the principle of protein-dye binding. Analytical Biochemistry 72:248-254.

Caldwell H D, Hitchcock P J 1984 Monoclonal antibody against a genus-specific antigen of Chlamydia species: location of the epitope on chlamydial lipopolysaccharide. Infection and Immunity 44:306-314.

Ceriotti G 1952 A microchemical determination of deoxyribonucleic acid. Journal of Biological Chemistry 198:297-303.

Dubois M, Gilles K A, Hamilton J K, Rebers P A, Smith F 1956 Colorimetric method for determination of sugar and related substances. Analytical Chemistry 28:350-356.

Fiske C H, Subbarow Y 1925 The colometric determination of phosphorus. Journal of Biological Chemistry 66:375-400.

Flesher A R, Insel R A 1978 Characterization of lipopolysaccharide of Haemophilus influenzae. Journal of Infectious Diseases 138:719-730.

Guymon L F, Esser M, Shafer W M 1982 Pyocin-resistant lipopolysaccharide mutants of Neisseria gonorrhoeae: alterations in sensitivity to normal human serum and polymyxin B. Infection and Immunity 36:541-547.

Hammond G W, Lian C J, Wilt J C, Ronald A R 1978 Antimicrobial susceptibility of Haemophilus ducreyi. Antimicrobial Agents and Chemotherapy 13:608-612.

Inzana T J 1983 Electrophoretic heterogeneity and interstrain variation of the lipopolysaccharide of Haemophilus influenzae. Journal of Infectious Diseases 148:492-499.

Jann B, Reske K, Jann K 1975 Heterogeneity of lipopolysaccharides. Analysis of polysaccharide chain lengths by sodium dodecylsulfate-polyacrylamide gel electrophoresis. European Journal of Biochemistry 60:239-246.

Jennings H J, Hawes G B, Adams G A, Kenny C P 1973 The chemical composition and serological reactions of lipopolysaccharides from subgroups A, B, X, and Y Neisseria meningitidis. Canadian Journal of Biochemistry 51:13471354.

Jourdian G W, Dean L, Roseman S 1971 The sialic acids. xi A periodate-resorcinol method for the quantitative estimation of free sialic acids and their glycosides. Journal of Biological Chemistry 246:430-435.

Karkhanis Y D, Zeltner J Y, Jackson J J, Carlo D J 1978 A new and improved microassay to determine 2-keto-3-deoxyoctonate in lipopolysaccharide of gram-negative bacteria. Analytical Biochemistry 85:595-601.

Laemmli U K 1970 Cleavage of structural proteins during the assembly of the head of bacteriophage $T_{4}$. Nature 227:680685.

Laine R A, Esselman W J, Sweeley C C 1972 Gas-liquid chromatography of carbohydrates. Methods in Enzymology 28:159-167.

Logan S M, Trust T J 1984 Structural and antigenic heterogeneity of lipopolysaccharides of Campylobacter jejuni and Campylobacter coli. Infection and Immunity 45:210-216.

Lüderitz O, Westphal O, Staub A M, Nikaido H 1971 Isolation and chemical and immunological characterization of bacterial lipopolysaccharides. In: Weinbaum et al. (eds) Microbial toxins. vol. 4. Academic Press Inc., New York, pp. 145233.
Medearis D N, Camitta B M, Heath E C 1968 Cell wall composition and virulence in Escherichia coli. Journal of Experimental Medicine 128:399-414.

Muschel L H, Larsen L J 1970 The sensitivity of smooth and rough gram-negative bacteria to the immune bactericidal reaction. Proceedings of the Society for Experimental Biology and Medicine 133:345-348.

Nelson B W, Roantree R J 1967 Analyses of lipopolysaccharides extracted from penicillin-resistant, serum-sensitive Salmonella mutants. Journal of General Microbiology 48:179-188.

Odumeru J A, Wiseman G M, Ronald A R 1984 Virulence factors of Haemophilus ducreyi. Infection and Immunity 43:607-611.

Odumeru J A, Wiseman G M, Ronald A R 1985 Role of lipopolysaccharide and complement in susceptibility of Haemophilus ducreyi to human serum. Infection and Immunity 50:495-499.

Olling S 1977 Sensitivity of gram-negative bacilli to serum bactericidal activity: a marker of the host parasite relationship in acute and persisting infections. Scandinavian Journal of Infectious Disease Suppl 10:7-40.

Parr T R, Bryan L E 1984 Lipopolysaccharide composition of three strains of Haemophilus influenzae. Canadian Journal of Microbiology 30:1184-1187.

Peppler M S 1984 Two physically and serologically distinct lipopolysaccharide profiles in strains of Bordetella pertussis and their phenotype variants. Infection and Immunity 43:224-232.

Reed W P, Albright E L 1974 Serum factors responsible for killing of Shigella. Immunology 26:205-215.

Rietschel E T, Galanos C, Lüderitz O 1984 Structure and conformation of the lipid A component of lipopolysaccharides. In: Rietschel E T (ed) Handbook of endotoxin, vol. I, Chemistry of endotoxin. Elsevier Science Publishers, pp 187 220.

Rowley D 1968 Sensitivity of rough gram-negative bacteria to the bactericidal action of serum. Journal of Bacteriology 95:1647-1650.

Scott T A, Melvin E H 1953 Determination of dextran with anthrone. Analytical Chemistry 25:1656-1661.

Smith R L, Gilkerson E 1979 Quantitation of glycosaminoglycan hexosamine using 3-methyl-2-benzothiazolone hydrazone hydrochloride. Analytical Biochemistry 98:478-480.

Stead A, Main J S, Ward M E, Watt P J 1975 Studies on lipopolysaccharides isolated from strains of Neisseria gonorrhoeae. Journal of General Microbiology 88:123-131.

Taylor P W 1975 Genetical studies of serum resistance in Escherichia coli. Journal of General Microbiology 89:57-66.

Tsai C M, Frasch C E 1982 A sensitive silver stain for detecting lipopolysaccharides in polyacrylamide gels. Analytical Biochemistry 119:115-119.

Westphal O, Jann K 1965 Bacterial lipopolysaccharides. Extraction with phenol-water and further applications of the procedure. Methods in Carbohydrate Chemistry 5:83-91.

Wiseman G M, Caird J D 1977 Composition of the lipopolysaccharide of Neisseria gonorrhoeae. Infection and Immunity 16:550-556.

Wright B G, Rebers P A 1972 Procedure for determining heptose and hexose in lipopolysaccharides. Modification of the cysteine-sulfuric acid method. Analytical Biochemistry 49:307-319.

Zoon K C, Scocca J J 1975 Constitution of the cell envelope of Haemophilus influenzae in relation to competence for genetic transformation. Journal of Bacteriology 123:666-677. 